\title{
TRUMPŲJŲ NUOTOLIŲ BE்GIKŲ REAKCIJOS TRUKMĖS IR JUDESIŲ DAŽNUMO YPATUMAI TRENIRUOTĖS VYKSME
}

\author{
Jūratė Stanislovaitiené ${ }^{1}$, Aleksas Stanislovaitis ${ }^{1}$, Edita Kavaliauskiené ${ }^{1}$, \\ Albertas Skurvydas ${ }^{1}$, Vaidas Mickevičius ${ }^{2}$, Ričardas Reimaris ${ }^{1}$ \\ Lietuvos kūno kultūros akademija ${ }^{1}$, Kauno technikos kolegija ${ }^{2}$, Kaunas, Lietuva
}

\begin{abstract}
Jūratė Stanislovaitienė. Biomedicinos mokslų daktarè. Individualių sporto šakų katedros asistentė. Mokslinių tyrimų kryptis — motorinės
\end{abstract} sistemos kompleksinė ir dinaminė adaptacija.

\section{SANTRAUKA}

Psichomotorinès reakcijos greitis ypač svarbus bégant trumpuosius nuotolius. Reakcijos trukmé (RT) svarbi kovojant dèl geriausiu rezultatu trumpuju nuotoliu varžybose. Mažesnè RT gali pagerinti 60 ir $100 \mathrm{~m}$ bégimo rezultatus. RT yra toks pat svarbus veiksnys kaip ir didžiausiojo bègimo greičio pasiekimas ir jo palaikymas. Trumpuju nuotoliu bègikui svarbi reakcija į starto teisejo šūvį. Reakcijos greitis reikšmingas judesio pradžioje. Judesiu dažnumas priklauso nuo centrinès nervu sistemos paslankumo, motoriniu centru gebèjimo greitai pereiti iš dirginimo ì slopinima, ir atvirkščiai. Svarbu žinoti, kad judesių dažnumas pasiekiamas, kai išorès pasipriešinimas yra mažiausias.

Tyrimo tikslas - ištirti ir palyginti trumpuju nuotoliu bègiku reakcijos trukmès ir judesiu dažnumo rodikliu kaita treniruotès vyksme.

Tyrimo uždaviniai: 1) nustatyti ir palyginti trumpuju nuotoliu bègiku reakcijos trukmés ypatumus ivvadiniu, parengiamuoju ir varžybu laikotarpiu; 2) nustatyti ir palyginti trumpuju nuotoliu bègiku judesiu dažnumo ypatumus įvadiniu, parengiamuoju ir varžybu laikotarpiu.

Reakcijos trukmé ir judesiu dažnumas buvo nustatomi naudojant reakciometra RA-1. Reakcijos trukme išmatuota tiriamajam atliekant po 10 judesiu dešine ranka, paskui kaire. Buvo nustatoma tiriamuju kairès ir dešinès rankos paprastoji RT ir apskaičiuojamos geriausios ir vidutinès RT reikšmès. Judesiu dažnumas nustatomas tiriamajam paèmus pagaliukq ir juo per 10 s kuo greičiau paliečiant prietaiso pagrinda.

Tyrimo duomenys parodè, kad trumpuju nuotoliu bègiku RT kitima lèmé skirtingo pobūdžio fizinis krūvis treniruotès vyksme. Nuo pirmo iki paskutinio testavimo dešinès ir kairès rankos RT reikšmingai pagerèjo (atitinkamai 14,53 ir 9,89\%) ( $p<0,05)$. Dešinés ir kairés rankos vidutine RT nuo pirmo iki paskutinio testavimo taip pat reikšmingai pagerèjo (atitinkamai 14,42 ir 11,05\%). Nors sprinteriu judesiu dažnumas skirtingu pratybu laikotarpiu nedaug pagerejo, statistiškai reikšmingo skirtumo neaptikome $(p>0,05)$.

Raktažodžiai: reakcijos trukmé, judesiu dažnumas, treniruotė.

\section{IVADAS}

$\mathrm{R}$ eakcijos trukmė (RT) yra svarbus komponentas kovojant dèl geriausių rezultatu trumpuju nuotolių bėgimo varžybose. RT sutrumpinimas gali pagerinti 60 ir $100 \mathrm{~m}$ bejgimo rezultatus. RT yra toks pat svarbus veiksnys kaip ir didžiausiojo bėgimo greičio pasiekimas bei jo palaikymas. RT yra tiesiogiai proporcinga galutiniam rezultatui: viena ar dvi šimtosios sekundès gali lemti galutini rezultatą, kai sprinteriai finišuoja greta. Sprinteriu psichomotorinès RT priklauso nuo: receptorių dirglumo ir impulso perdavimo greičio; signalo perdavimo greičio centrinèje nervų sistemoje; tolesnès veiklos sprendimo prièmimo greičio; eferentinio signalo perdavimo; impulso perdavimo i raumenis greičio ir raumeninių skaidulu susitraukimo greičio. Visų šių RT komponentų dydžiai gali būti nevienodi - vieno sprinterio yra geresnis receptoriu dirglumas, ta- 
čiau blogesnis signalo perdavimo greitis, kito atvirkščiai (Платонов, 2004). Judesių dažnumas (JD) priklauso nuo centrinès nervų sistemos paslankumo, motorinių centrų gebejjimo greitai pereiti iš dirginimo į slopinimą, ir atvirkščiai (Skurvydas, 2008). Reakcijos greitis rodo žmogaus centrinès nervų sistemos psichomotorinių procesų greiti, JD - centrinès nervu sistemos psichomotoriniu procesu greitị ir gebejimą greitai pereiti iš vienos būsenos i kitą (Magill, 2007). Manytume, kad šio tyrimo rezultatai suteiks treneriams žinių apie trumpujų nuotolių bėgikų treniruotès valdymo vyksmą ir jo kryptinguma, papildys sporto mokslo sriti, nagrinejjančią naujų treniruotès valdymo priemoniu taikymą sportinejje praktikoje. Tyrimo tikslas - ištirti ir palyginti trumpujų nuotolių bègikų reakcijos trukmès ir judesių dažnumo rodiklių kaitą treniruotès vyksme.

\section{TYRIMO METODIKA}

Tiriamieji. Buvo tiriami trumpujų nuotolių bègikai ( $\mathrm{n}=12$; amžius $-20,14 \pm 2,22 \mathrm{~m}$., ūgis $181,89 \pm 5,97 \mathrm{~m}$, svoris $-74,14 \pm 7,55 \mathrm{~kg}$ ).

Reakcijos trukmès ir judesių dažnumo nustatymas. RT ir JD nustatytas naudojant reakciometrą RA-1. Tiriamasis buvo sodinamas ant kėdès, kurios aukštis sureguliuotas taip, kad tarp šlaunies ir blauzdos būtų 90 laipsnių kampas. Nustatant RT, tiriamieji atliko po 10 judesių dešine ir kaire ranka. Dešine ranka jie kuo greičiau turèjo sureaguoti i žalios šviesos impulsą, kaire - i raudonos. Nustatant judesių dažnumą, tiriamasis pagaliuku per $10 \mathrm{~s}$ turejo kuo greičiau paliesti prietaiso pagrindą. Buvo skaičiuojami smūgiai, suduoti i prietaisa.

Tyrimo eiga. Tiriamieji pamokyti ir supažindinti su tyrimo eiga. Trumpuju nuotolių bėgikai buvo testuojami ịvadiniu, parengiamuoju ir varžybų laikotarpiu. Testavimai atlikti tuo pačiu paros laiku, prieš pratybas arba prieš varžybas. Buvo nustatoma tiriamuju kairès ir dešinès rankos paprastoji RT ir apskaičiuojamos geriausios bei vidutinès RT reikšmès, ìvertinamas judesių dažnumas. Ivadiniu laikotarpiu atlikti septyni testavimai. Šiuo laikotarpiu dominavo lengvi aerobinio pobūdžio ir bendrojo fizinio rengimo krūviai. Sportininku organizmas buvo rengiamas atlaikyti didelius ir intensyvius fizinius krūvius. Parengiamuoju laikotarpiu atlikta trylika testavimų. Tuo metu vyravo didžiausi fiziniai krūviai. Pradžioje buvo ugdoma jègos ištvermè - organizmo gebèjimas ilgai ir daug kartų išugdyti optimalią jègą. Jègos ištvermè priklauso nuo to, kaip organizmas įveikia maksimalias ir išorines pasipriešinimo jègas. Paskui sportininkai savaitę ilsejjosi - turejjo atgauti fizines jègas prieš jègos greitumo ir greitumo jègos fizinius krūvius. Jau tada vienas ar kitas pratimas buvo atliekamas per trumpiausią laiką, intensyvumas buvo maksimalus, vyravo ilgos poilsio pauzès, pratimai buvo mažai kartojami. Varžybu laikotarpiu atlikti trys testavimai. Šiuo laikotarpiu didžiausias krūvis sportininkams tekdavo per varžybas. Varžybų laikotarpiu per pratybas sportininkai gerindavo greitumo fizinę ypatybę. Be to, jie atlikdavo aerobinio pobūdžio fizinius krūvius, šitaip spartindami organizmo energijos atsigavima nuo vienų iki kitų varžybų.

Matematinė statistika. Išanalizavus tyrimo duomenis, skaičiuotas aritmetinis rezultatų vidurkis $(\overline{\mathrm{x}})$, vidutinis standartinis nuokrypis, skirtumo tarp vidurkių statistinis patikimumas (p). Skirtumo tarp aritmetinių vidurkių reikšmingumas buvo nustatomas pagal dvipusi priklausomų imčių Studento $t$ kriterijų. Skirtumas statistiškai reikšmingas, kai $\mathrm{p}<0,05$.

\section{REZULTATAI}

Reakcijos trukmės kaita treniruotės vyksme. Tyrimo rezultatai rodo RT kaita treniruotès vyksme. Po pirmo testavimo geriausia dešinès rankos RT buvo lygi 160,75 $\pm 12,07 \mathrm{~ms}$, kairès rankos $159,67 \pm 19,18$ ms. Sumažèjus fiziniams krūviams ir sportininkams pasiekus optimalią fizinę formą, labai pagerèjo tiek dešinès, tiek kairès rankos RT. Paskutinio testavimo metu ji buvo atitinkamai lygi $137,4 \pm 11,35 \mathrm{~ms}$ ir $143,88 \pm 10,48 \mathrm{~ms}$. Vadinasi, geriausia RT turejo tendenciją gerèti. Tai rodo statistiškai reikšmingas skirtumas, lyginant pirmo ir paskutinio testavimo RT duomenis $(\mathrm{p}<0,05)$ (1 pav.).

Išanalizavus geriausių dešinès ir kairès rankos RT reikšmių kaitą treniruotės vyksme matyti, kad Łvadiniu laikotarpiu geriausia dešinės rankos RT pastebimai gerejo. Po pirmo testavimo RT buvo lygi $160,75 \pm 12,07 \mathrm{~ms}$, o šio laikotarpio pabaigoje $-147,17 \pm 18,55 \mathrm{~ms}$. Tai lèmè lengvos bendrojo fizinio pasirengimo pratybos. Parengiamojo laikotarpio pradžioje išryškèjo didelis dešinès rankos RT pablogejjimas - devinto testavimo metu RT buvo 159,4 $\pm 16,32 \mathrm{~ms}$. Visgi kitų testavimu metu dešinès rankos RT buvo stabili, per paskutini $-144,9 \pm 17,14 \mathrm{~ms}$. Šiuos rezultatus galejo lemti nesunkios parengiamojo laikotarpio pradžios pratybos. Paskui organizmas adaptavosi prie fizi- 

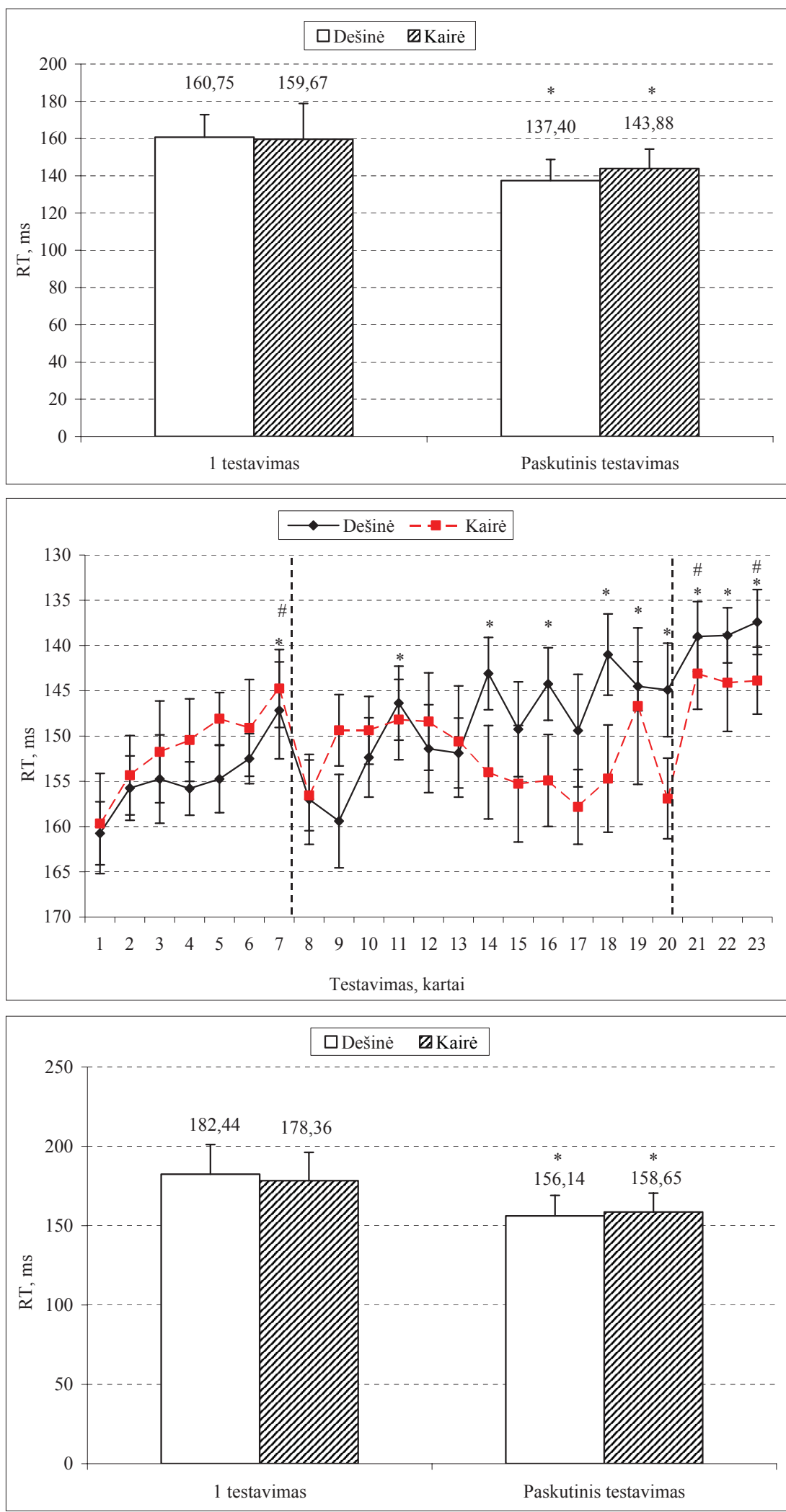

1 pav. Dešinès ir kairès rankos geriausios RT reikšmès pirmo ir paskutinio testavimo metu

Pastaba. * $-\mathrm{p}<0,05$, lyginant pirmo ir paskutinio testavimo RT duomenis.

2 pav. Dešinès ir kairès rankos geriausiu RT reikšmių kaita treniruotès vyksme

Pastaba. * - p $<0,05$, lyginant pirmo ir kitu testavimų dešinès rankos RT duomenis; \#$\mathrm{p}<0,05$, lyginant pirmo ir kitų testavimu kairès rankos RT duomenis.

3 pav. Dešinès ir kairès rankos vidutinès RT reikšmès pirmo ir paskutinio testavimo metu

Pastaba. * - p $<0,05$, lyginant pirmo ir paskutinio testavimo RT duomenis. nių krūvių ir RT stabilizavosi. Varžybų laikotarpiu sumažèjus fiziniams krūviams ir sportininkams pasiekus optimalią fizinę formą, RT turèjo tendenciją gerèti, o paskutinio testavimo metu ji buvo geriausia $-137,4 \pm 11,35 \mathrm{~ms}$. Ivadiniu laikotarpiu kairès rankos RT turejo tendenciją gerèti. Po pirmo testavimo RT buvo lygi 159,67 $\pm 19,18 \mathrm{~ms}$, šio lai- kotarpio pabaigoje $-144,17 \pm 14,92 \mathrm{~ms}$. Tai lèmè lengvos bendrojo fizinio pasirengimo pratybos. $\mathrm{Pa}-$ rengiamojo laikotarpio pradžioje pastebètas didelis kairès rankos RT pablogèjimas, aštunto testavimo metu RT buvo lygi 156,56 $\pm 11,72 \mathrm{~ms}$. Kitų testavimų metu kairès rankos RT reikšmès gerèjo, bet per paskutini parengiamojo laikotarpio testavima 
4 pav. Dešinès ir kairès rankų vidutinių RT reikšmių kaita treniruotės vyksme palyginimas
Pastaba. * - p $<0,05$, lyginant pirmo ir kitu testavimų dešinès rankos RT duomenis; \#$\mathrm{p}<0,05$, lyginant pirmo ir kitų testavimu kairès rankos RT duomenis.

5 pav. Judesių dažnumo rezultatai pirmo ir paskutinio testavimo metu
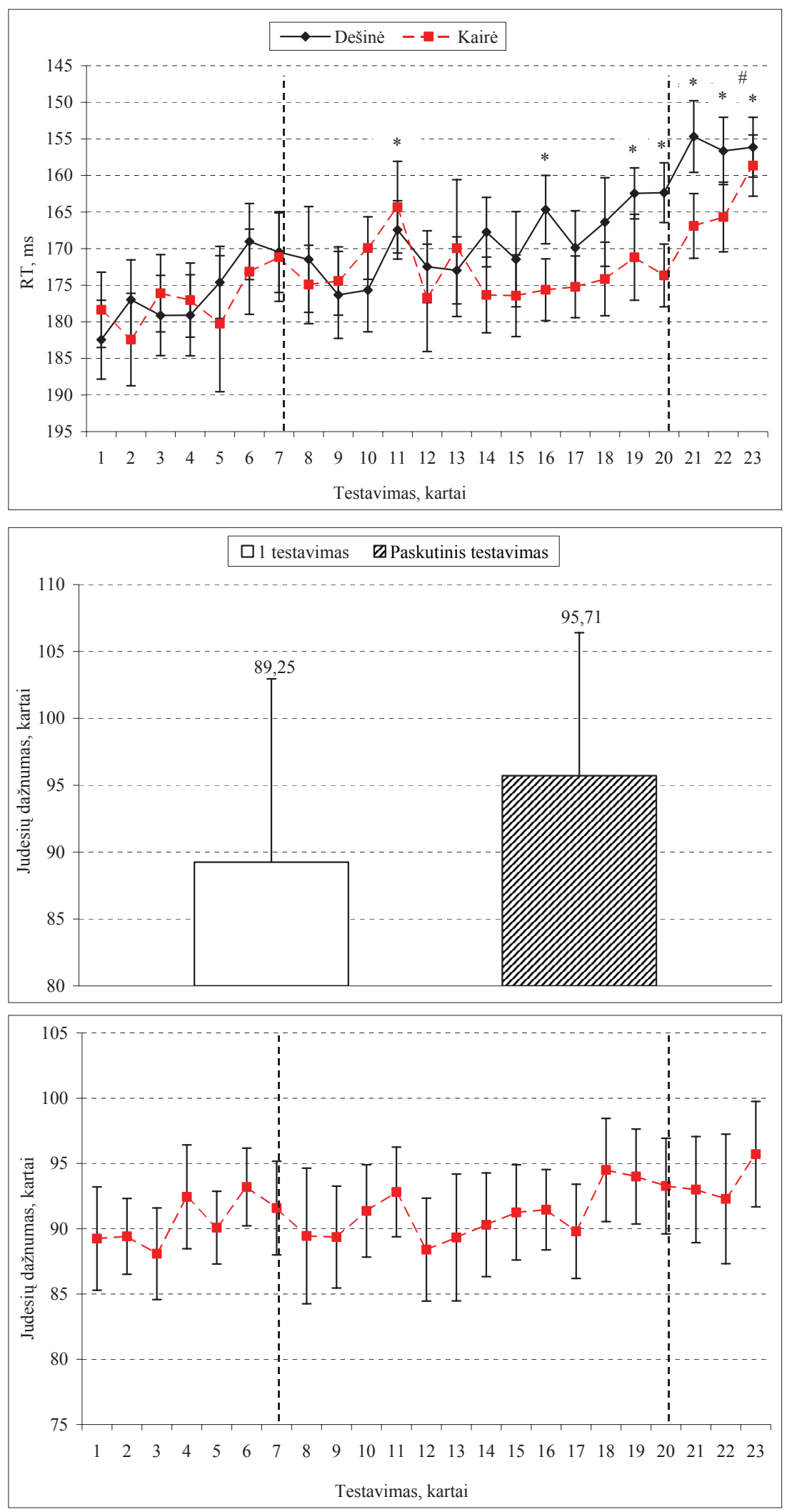

RT labai pablogejo $-156,90 \pm 14,08$ ms. Tokius rezultatus galèjo lemti parengiamojo laikotarpio pabaigoje dominavę maksimalūs fiziniai krūviai. Varžybų laikotarpiu sumažèjus fiziniams krūviams ir sportininkams pasiekus optimalią fizinę formą, RT turejo tendenciją gerèti ir paskutinio testavimo metu ji buvo geriausia $-143,88 \pm 10,48 \mathrm{~ms}$.
Analizuojant trumpujų nuotolių bėgiku geriausias dešinès ir kairès rankos RT reikšmes, buvo pastebètas statistiškai reikšmingas skirtumas, lyginant pirmo ir kitų testavimų dešinès ir kairès rankos RT duomenis $(p<0,05)$. Šis skirtumas ypač ryškus po paskutinio testavimo: dešinès rankos RT $137,4 \pm 11,35 \mathrm{~ms}$, kairès $-143,88 \pm 10,48 \mathrm{~ms}$. 
Ivadiniu laikotarpiu išryškèjo geresnès kairès rankos RT reikšmès. Parengiamuoju ir varžybu laikotarpiu dešinès rankos RT reikšmès buvo daug geresnès nei kairès rankos geriausiosios. Taip atsitiko del to, kad visu tiriamuju dominuojanti ranka buvo dešine ir jie gebejjo greičiau išmokti veiksmą šia ranka (2 pav.).

Analizuojant dešinès ir kairès rankos vidutines RT reikšmes pastebetas statistiškai reikšmingas skirtumas, lyginant pirmo ir paskutinio testavimo testavimo duomenis $(\mathrm{p}<0,05)$. Po pirmo testavimo dešinès rankos vidutinès RT reikšmès buvo lygios $182,44 \pm 18,69 \mathrm{~ms}$, kairès $-178,3 \pm 17,82 \mathrm{~ms}$. Paskutinis testavimas rodo, kad didžiausia RT reikšmé pagerèjo ir dešinès rankos jau siekẻ $156,14 \pm 12,91 \mathrm{~ms}$, kairès $-158,65 \pm 11,82 \mathrm{~ms}$ (3 pav.).

Tiriant dešinès rankos vidutines RT reikšmes pastebetas statistiškai reikšmingas skirtumas, lyginant pirmo ir kitų testavimų duomenis $(\mathrm{p}<0,05)$. Ivadinio laikotarpio pradžioje po pirmo testavimo dešinès rankos RT buvo lygi 182,44 $\pm 18,69 \mathrm{~ms}$, o šio laikotarpio pabaigoje - 170,47 $\pm 19,13 \mathrm{~ms}$. Parengiamojo laikotarpio pradžioje išryškejjo dešinès rankos RT pablogèjimas. Devinto testavimo metu RT buvo lygi 176,32 $\pm 18,78 \mathrm{~ms}$. Per kitus parengiamojo laikotarpio testavimus dešinès rankos RT gerejo ir šio laikotarpio pabaigoje siekè 162,35 $\pm 13,55 \mathrm{~ms}$. Varžybu laikotarpiu sumažèjus fiziniams krūviams ir sportininkams pasiekus optimalią fizinę formą, dešinès rankos vidutine reakcija ir paskutinio testavimo metu buvo geriausia $-156,14 \pm 12,91 \mathrm{~ms}$. Analizuojant kairès rankos vidutines RT reikšmes buvo pastebètas statistiškai reikšmingas skirtumas, lyginant skirtingu pratybu laikotarpiu duomenis $(\mathrm{p}<0,05)$. Visų testavimų metu kairès rankos RT reikšmes gerejo. Didžiausias nuosmukis pastebėtas ivvadiniu laikotarpiu, antro testavimo metu, kai RT reikšmès buvo 182,42 $\pm 21,90 \mathrm{~ms}$. Geriausios kairès rankos vidutinès RT reikšmès buvo parengiamuoju laikotarpiu $(148,18 \pm 14,73)$ ir per paskutini varžybų laikotarpio testavimą $(158,65 \pm 11,82 \mathrm{~ms})$. Didžiausias dešinès ir kairès ranku vidutiniu RT reikšmiu skirtumas nustatytas parengiamojo laikotarpio pabaigoje, kai dešinès rankos vidutinès RT reikšmès buvo lygios $162,36 \pm 13,55 \mathrm{~ms}$, kairès $-173,67 \pm 13,55 \mathrm{~ms}$. Varžybų laikotarpiu dešinès ir kairès rankų RT reikšmiu didžiausias skirtumas nustatytas testavimo pradžioje. Tada dešinès rankos vidutinès RT reikšmès buvo lygios $154,68 \pm 14,69 \mathrm{~ms}$, kairès $-166,90 \pm 14,65 \mathrm{~ms}$ (4 pav.).
Judesių dažnumo kaita treniruotès vyksme. Analizuojant judesių dažnumo rezultatus pirmo ir paskutinio testavimo metu matyti, kad per pirmą testavimą judesių dažnumas sieke $89,25 \pm 13,71$ kartų, o varžybų laikotarpio pabaigoje $-95,71 \pm 10,69$ kartuc (5 pav.).

Išanalizavus trumpujų nuotolių bėgikų judesių dažnumo kaitą treniruotès vyksme matyti: nors sprinteriu judesių dažnumas skirtingu pratybu laikotarpiu nedaug pagerèjo, bet statistiškai reikšmingo skirtumo neaptikome ( $p>0,05)(6$ pav.).

\section{REZULTATŲ APTARIMAS}

Fiziniais pratimais galima pagerinti sportininkų reakcijos trukmę, tačiau pažanga būna nelabai didelè, nes daugiausia ši rodiklị lemia genotipinès adaptacijos raida (Sanders, 1998; Ando et al., 2002; Rogers et al., 2003). RT nepriklauso nuo sportininkų treniruotumo (Joch, 1980; Soares et al., 1987), tačiau mūsų tyrimas įrodè, kad trumpujų nuotolių bėgikų RT kinta priklausomai nuo taikomo fizinio krūvio treniruotės vyksme.

Geriausia dešinès ir kairès rankos RT reikšmè nuo pirmo iki paskutinio testavimo reikšmingai gerejo (atitinkamai 14,53 ir 9,89\%). Manytume, kad dèl tiriamuju pasiektos geriausios sportinès formos varžybu laikotarpiu pagerejjo ir kiti rodikliai (t. y. reakcijos trukmè), kurie turi tiesiogini ryši su varžybų rezultatu. Kokybiškai treniruojantis, tinkamai derinant krūvio apimtị ir intensyvumą, gerejja ir tobuleja visi sportinès formos rodikliai, pasiekiamas didelis atskirų sportininko organų ir sistemų pajègumas ir darni jų veiklos koordinacija (Stanislovaitis ir kt., 2006).

Vidutinè dešinès ir kairès rankos RT reikšmè nuo pirmo iki paskutinio testavimo reikšmingai gerèjo (atitinkamai 14,42 ir 11,05\%). Galima pastebèti, kad igijus puikią sportinę formą labiausiai pagerèjo dešinès rankos tiek geriausios, tiek vidutinès RT reikšmès, dešinès rankos RT taip pat buvo geresnè nei kairès. Ko gero, taip nutiko dèl to, kad tiriamujų dešinè ranka dominuojanti ir ji buvo greitesnè už kairę (nedominuojančią) (Kerr, 1963). Manytume, didesni RT gerejjimą lèmé tai, kad dominuojanti ranka geba greičiau prisitaikyti aptikdama vizualini stimulą ir atlikdama mechanini veiksmą, nes reikalingas laiko tarpas informacijai, aptiktai dešine kūno dalimi, perduoti ị kairę, kuri atlieka veiksmą (Marzi, 1991).

Išanalizavus dešinès ir kairès rankos RT kitimą per visą trumpujų nuotolių bėgikų rengimąsi galima teigti, kad įvadiniu laikotarpiu dešinès ir kairès 
rankos geriausia RT pastebimai gerèjo. Tai lèmè lengvos bendrojo fizinio rengimo pratybos. Taip pat nenustatyta, kad įvadiniu laikotarpiu geresnès RT reikšmès buvo karès rankos. Tai galima paaiškinti M. Peters ir J. Ivanoff (1999) teigimu, kad dešinè ranka, kaip dominuojanti, yra lètesnè nei kairè (nedominuojanti), nes žmonès gyvenimiškoje veikloje atlieka labai daug lètú judesių, kurie ir sulètina, ir nuvargina dominuojančią (vyraujančią) ranką, o kairè tuo metu ilsisi ir, žinoma, dèl to ji greitesnè. Parengiamojo laikotarpio pradžioje išryškejjo didelis RT pablogejimas, nes tuo metu treniruotès vyksme dominavo sunkus jègos ištvermès fizinis krūvis, kuris lèmè staigų RT pablogèjimą. Šiuo laikotarpiu išryškejjo dešinès rankos pranašumas prieš kairiają, nes, manytume, dominuojanti ranka atsparesnè nuovargiui. Varžybų laikotarpiu sumažèjus fiziniams krūviams ir sportininkams pasiekus optimalią sportinę formą, RT turèjo tendenciją gerèti ir paskutinio testavimo metu ji buvo geriausia - 137,4 $\pm 11,35 \mathrm{~ms}$. Manytume, kad toks banguotas RT kitimas rodo sportinès formos igijimo kaita, nes sportinè forma taip pat yra banguota ir priklauso nuo sportininko treniruotumo, organizmo funkcinių sistemų darbingumo ir išorès sąlygu (Karoblis ir kt., 2002).

Nors sprinterių judesių dažnumas skirtingu treniruočių laikotarpiu nedaug pagerèjo, tačiau statistiškai reikšmingo skirtumo neaptikome
( $p>0,05)$. Pagal judesių dažni iš dalies galima spręsti apie centrinès nervų sistemos funkcinę būklę. Nuo sujaudinimo ir slopinimo keitimosi, centrinès nervų sistemos pusiausvyros priklauso judesiu atlikimo tempas, ritmas bei gebejjimas greitai išmokti sudètingus, didelio dažnio judesius (Shephard, 2001; McCarthy et al., 2002). Pirmo testavimo metu judesiu dažnumas sieke $89,25 \pm 13,71$ kartų, varžybų laikotarpio pabaigoje - jau 95,71 $\pm 10,69$ kartų. Tai patvirtina teigini, kad gerèjant greitumą lavinančiu šaku sportininku treniruotumui, dideja ir jų judesių dažnumas. Iš maksimalaus judesių dažnio kaitos per ilgesni laiką galima vertinti centrinès nervų sistemos gebejjimą ilgą laiką veiksmingai valdyti judesius (Skernevičius ir kt., 2004).

\section{IŠVADOS}

1. Trumpujų nuotolių bėgikų reakcijos trukmès kitimą reikšmingai lèmé taikytas skirtingo pobūdžio fizinis krūvis treniruotès vyksme. Sprinteriu reakcijos trukmė skirtingu pratybu laikotarpiu (lyginant parengiamaji ir varžybų) reikšmingai pagerëjo $(\mathrm{p}<0,05)$.

2. Trumpujjų nuotolių bėgikų judesių dažnumas îvadiniu, parengiamuoju ir varžybų laikotarpiu nedaug pagerejo, bet statistiškai reikšmingo skirtumo nenustatème ( $\mathrm{p}>0,05)$.

\section{LITERATŪRA}

Ando, S., Kida, N., Oda, S. (2002). Practice effects on reaction time for peripheral and central visual fields. Perceptual and Motor Skills, 95 (3), 747-752.

Joch, W. (1980). Zum Reaktion vermogen von Boxern [Reaction ability in boxers]. Deutche Zeitschrift Sportmedecin, 31, 7-8.

Karoblis, P., Raslanas, A., Steponavičius, K. (2002). Didelio meistriškumo sportininku rengimas. Vilnius: Egalda.

Kerr, M. (1963). Cerebral dominance in reaction time responses. British Journal of Psychology, 54, 325-336.

Magill, R. A. (2007). Motor Learning and Control: Concepts and Applications. New York: McGraw-Hill.

Marzi, C. A. (1991). Is interhemispheric transfer of visuomotor information asymmetric? Evidence from a metaanalysis. Neuropsychologia, 29, 1163-1177.

McCarthy, J. P., Pozniak, N., Busso, T. (2002). Neuromuscular adaptations to concurrent strength and endurance training. Medicine and Science in Sports and Exercise, 34 (3), 511-519.

Peters, M., Ivanoff, J. (1999). Performance asymmetries in computer mouse control of right-handers, and left handers with left- and right-handed mouse experience. Journal of Motor Behavior, 31 (1), 86-94.

Rogers, M. W., Johnson, M. E., Martinez, K. M.,
Mille, M. L., Hedman, L. D. (2003). Step training improves the speed of voluntary step initiation in aging. The Journals of Gerontology, Series A, 58 (1), 46-52.

Sanders, A. F. (1998). Elements of Human Performance: Reaction Processes and Attention in Human Skill. Mahwah, New Jersey: Lawrence Erlbaum Associates, Publishers.

Shephard, R. J. (2001). Absolute versus relative intensity of physical activity in a dose-response context. Medicine and Science in Sports and Exercise, 33 (6), 400-418, $419-420$.

Skernevičius, J., Raslanas, A., Dadelienè, R. (2004). Sporto mokslu tyrimu metodologija. Vilnius: LISC.

Skurvydas, A. (2008). Judesiu mokslas: raumenys, valdymas, mokymas, reabilitavimas, sveikatinimas, treniravimas, metodologija. Kaunas.

Soares, J., Osoro, L. A. N., Palafox, G. H. M. (1987). Comparative study of simple visuo-hand reaction time in athletes of various sports. Kinesis, 1, 77-85.

Stanislovaitis, A., Grūnovas, A., Butkus, V. (2006). Truтрији nuotoliu bégimas. Kaunas.

Платонов, В. Н. (2004). Система подготовки спортсменов в олимпийском спорте. Киев: Опимпийская литература. 


\title{
PECULIARITIES OF REACTION TIME AND FREQUENCY OF MOVEMENTS OF SHORT DISTANCE RUNNERS IN THE TRAINING PROCESS
}

\author{
Jūratė Stanislovaitiené ${ }^{1}$, Aleksas Stanislovaitis ${ }^{1}$, Edita Kavaliauskiené ${ }^{1}$, Albertas Skurvydas ${ }^{1}$, \\ Vaidas Mickevičius ${ }^{2}$, Ričardas Reimaris ${ }^{1}$ \\ Lithuanian Academy of Physical Education ${ }^{1}$, Kaunas Technical College ${ }^{2}$, Kaunas, Lithuania
}

\begin{abstract}
Psychomotor reaction speed is of great importance when running short distances. Reaction time is a significant component striving for the best results in short distance running. Making reaction time shorter can improve results in 60 and $100 \mathrm{~m}$ running. Reaction time is as important as the achievement and maintenance of maximum running speed. In short distance running it is very important to react quickly to the starter pistol of the official. Reaction speed is significant at the beginning of a movement. The frequency of movement depends on the mobility of the central nervous system and the ability of motor centers to move from stimulation to inhibition quickly, and vice versa. It is important to know that the frequency of movements is achieved when the external resistance is minimal.

The aim of the study was to investigate and compare the peculiarities of reaction time and frequency of movements of short distance runners in the process of training. Research objectives were as follows: 1) to establish and compare the peculiarities of reaction time of short distance runners in the introductory, preparation and competition periods; 2) to establish and compare the peculiarities of the frequency of movements of short distance runners in the introductory, preparation and competition periods.

Reaction time and the frequency of movements were measured applying the reaction-meter RA-1. For the estimation of the reaction time the subjects performed 10 movements with their right hand, then with their left hand. We established the simple reaction time of the subjects' right and left hands, and then we calculated the best and the mean values of their reaction time. For the estimation of the frequency of movements the subjects had to take a "stick" and to touch the base of a device with it in $10 \mathrm{~s}$ as quickly as possible.

The findings of our research indicated that the changes in the reaction time of short distance runners were significantly affected by the different physical loads in the training process. From the first till the last testing the best reaction time of the right and the left hand significantly improved (14.53 and $9.89 \%$ respectively) $(\mathrm{p}<0.05)$. We also established that mean reaction time between the first and the last testing also significantly improved (14.42 and $11.05 \%$ respectively). Though the frequency of sprinters' movements in different periods of the training sessions slightly improved, we did not find statistically significant differences $(p>0.05)$.
\end{abstract}

Keywords: reaction time, frequency of movements, sprint, training session. 